\title{
Productive characteristics of banana genotypes submitted to different irrigation water depths under Cerrado conditions ${ }^{1}$
}

\section{Características produtivas de genótipos de bananeira submetidas a diferentes lâminas de irrigação em condições de cerrado}

\author{
Luciana Borges e Silva ${ }^{2 *}$; Jorge Luís do Nascimento ${ }^{3}$; Ronaldo Veloso Naves ${ }^{3}$; \\ Juracy Rocha Braga Filho4; Wilian Henrique Diniz Buso; \\ Eli Regina Barboza de Souza ${ }^{3}$
}

\begin{abstract}
Irrigation management associated with other banana agricultural practices can provide an increased productivity and improved fruit quality. This study assessed the productive characteristics of banana genotypes under different irrigation water depths. The experiment was conducted at the experimental area of the School of Agronomy (EA/UFG) in Goiânia, GO, Brazil. The experimental design was a split-plot randomized block design, in which four irrigation water depths $(30,65,100$, and $135 \%$ of crop potential evapotranspiration, ET ${ }_{\mathrm{pc}}$ ) composed the plots and three genotypes ('FHIA 18', 'GrandeNaine', and 'Prata') the subplots, with a spacing of $2.5 \times 1.6 \mathrm{~m}$. During the experimental period (first production cycle), the total precipitation was $1719.20 \mathrm{~mm}$. Characterization of genotype development and yield was performed with the following assessments: bunch mass $(\mathrm{kg})$, number of hands, stalk mass $(\mathrm{kg})$, fruit diameter of the second hand $(\mathrm{mm})$, fruit length of the second hand $(\mathrm{cm})$, mass of the second hand $(\mathrm{kg})$, number of fruits of the second hand, total number of fruits, and number of damaged fruits. The cultivar 'FHIA 18', differently from the others, showed a significant response to irrigation water depths on productivity. In the genotypes 'Grande-Naine' and 'Prata', an influence of irrigation was observed only on external and visual characteristics of fruit (diameter, length, and number of damaged fruits). In the genotype 'Prata', the irrigation water depth of $965 \mathrm{~mm}$ allowed fruit production with a larger diameter. Fruit length in the genotype 'Prata' increased linearly as water depth increased. The use of irrigation promoted a reduction in the number of damaged fruits in the genotypes 'FHIA 18 ' and 'Grande-Naine'.
\end{abstract}

Key words: Banana farming. Irrigation management. Musa sp. Yield.

\section{Resumo}

O manejo da irrigação associado a outras práticas agrícolas pode propiciar aumento de produtividade e melhoria na qualidade dos frutos. Neste estudo foram avaliadas as características produtivas de genótipos de bananeira, sob diferentes lâminas de irrigação. $\mathrm{O}$ experimento foi conduzido na área experimental da Escola de Agronomia (EA/UFG), localizada no município de Goiânia-GO. O delineamento

Parte da dissertação do primeiro autor.

2 Prof., Instituto Federal de Educação, Ciência e Tecnologia, IF Goiano, Ceres, GO, Brasil. E-mail: luciana.silva@ifgoiano.edu.br

3 Profs., Programa de Pós-Graduação em Agronomia, Escola de Agronomia, Universidade Federal de Goiás, UFG, GO, Brasil. E-mail: jln.agro@gmail.com; ronaldo.veloso@agro.ufg.br; eliregina1@gmail.com

4 Fiscal Estadual Agropecuário, Agrodefesa, GO, Brasil. E-mail: juracyr@yahoo.com.br

5 Prof., Programa de Pós-Graduação em Irrigação no Cerrado, Instituto Federal de Educação, Ciência e Tecnologia, IF Goiano, Ceres, GO, Brasil. E-mail: wilian.buso@ifgoiano.edu.br

* Author for correspondence

Received: Aug. 24, 2016 Approved: May 19, 2017 
experimental adotado foi blocos casualizados, com parcelas subdivididas, em que quatro lâminas de irrigação constituíram as parcelas (30, 65, 100 e 135\% da Evapotranspiração potencial - ETpc) e três genótipos (FHIA 18, Grande Naine e Prata) as subparcelas, com espaçamento 2,5 x 1,6 m. Durante o período experimental (primeiro ciclo de produção) a precipitação pluvial total foi de 1719,20 mm. A caracterização do desenvolvimento e do rendimento dos genótipos foi realizada com as seguintes avaliações: massa do cacho $(\mathrm{kg})$; número de pencas; massa do engaço $(\mathrm{kg})$; diâmetro do fruto da segunda penca $(\mathrm{mm})$; comprimento do fruto da segunda penca $(\mathrm{cm})$; massa da segunda penca $(\mathrm{kg})$; número de frutos da segunda penca; número de frutos total e número de frutos defeituosos. A cultivar FHIA 18, diferentemente das demais, mostrou resposta significativa às lâminas de irrigação na produtividade. Nos genótipos Grande Naine e Prata houve influência da irrigação apenas sobre as características externas e visuais do fruto (comprimento e número de frutos defeituosos). No genótipo 'Prata', a irrigação com $965 \mathrm{~mm}$ proporcionou a produção de frutos com maior diâmetro. O comprimemto dos frutos de banana 'Prata' aumentaram linearmente com o aumento da lâmina de irrigação. A irrigação promoveu a redução do número de frutos danificados nos genótipos 'FHIA 18' e 'Grande-Naine'

Palavras-chave: Bananicultura. Manejo de irrigação. Musa sp. Produção.

\section{Introduction}

Brazil is the fifth largest banana producer in the world, and this fruit is the most consumed in the country (FAO, 2014). Banana cultivation has a production of 7,023 million tons, with an average productivity of $14.63 \mathrm{t} \mathrm{ha}^{-1}$ and a planted area of 487,902 ha, standing out as the largest Brazilian producers the states of São Paulo, Bahia, Minas Gerais, and Santa Catarina (IBGE, 2015).

In Brazil, banana-farming systems have been losing competitiveness because of the wide variability of technological levels adopted by growers. In addition, the absence or inadequacy of irrigation management and cultural practices to maintain this activity impair the fruit quality, making the crop less competitive (NOMURA et al., 2013).

The Cerrado region has a well-defined dry and rainy season, concentrating $80 \%$ of precipitation in the rainy season, which occurs from November to April (NIMER; BRANDÃO, 1989; GOEDERT, 1989, and ASSAD; EVANGELISTA, 1994). Precipitation in most growing regions is insufficient for satisfactory growth and development of plants, and it may influence the quantity and quality of fruits. Irrigation use led to an average productivity of $54.34,54.90,28.78$, and $28.88 \mathrm{t} \mathrm{ha}^{-1}$ for the genotypes Thap Maeo, 'Grande-Naine', “FHIA 18 ", and 'Prata', respectively, in this region
(BRAGA FILHO et al., 2011).

Banana tree is a fast growing and large-sized herbaceous plant that produces more than 300 tons of fresh matter per hectare at each crop. Thus, this crop consumes high volumes of water and nutrients (LICHTEMBERG; LICHTEMBERG，2011). Irrigation in Brazilian banana farming, which has been used in a supplementary way, has emerged as an indispensable agricultural technique that provides increased productivity, improved fruit quality, and off-season harvestings and plantings. However, for an efficient water use, the knowledge of soilclimate-plant-irrigation management interrelations is required. Thus, if an inadequate irrigation management is performed, the productive potential improvement of cultivated plants is unable to be achieved, with any promising prospects for banana farming, regardless the used irrigation method. Studies involving assessments of cultivars in different regions are important and offer producers cultivation options, as well as collaborating with regional development of this crop (BORGES et al., 2011; CAMOLESI et al., 2012; RAMOS et al., 2009) and researches on irrigation management.

The number of banana cultivars traditionally used in Brazil is reasonably great. However, few cultivars present the agronomic potential for commercial exploitation with a high productivity, tolerance to 
pests, diseases, drought, and cold, reduced size, and shorter production cycle (NOMURA et al., 2013). Thus, for the introduction of new banana cultivars that present desirable productive and phytosanitary characteristics in production areas, studies that characterize the productive and vegetative behavior at different edaphoclimatic conditions are necessary.

The lack of information on the productive behavior of irrigated banana plantations under edaphoclimatic conditions of Cerrado evidences the need to intensify the researches on irrigation management in this crop. Therefore, the aim of this study was to assess the effect of four irrigation levels on the productivity of three banana genotypes.

\section{Material and Methods}

The experiment was carried out at the experimental area of the School of Agronomy, Federal University of Goiás (EA/UFG), on a medium-textured dystrophic Perferric Red Latosol. Planting was carried out on May 24, 2001, and the assessments performed from May 2001 to October 2002.

The experimental design was a split-plot randomized block design in a $4 \times 3$ factorial scheme with four replications. Four irrigation water depths $(30,65,100$, and $135 \%$ of crop potential evapotranspiration, $\mathrm{ET}_{\mathrm{pc}}$ ) were applied in the plots. These water depths, when added to the precipitation, corresponded to 2003.95, 2349.95, 2668.36, and $2995.09 \mathrm{~mm}$, respectively. The second treatment factor (subplots) was composed of three banana genotypes: "FHIA 18”, 'Grande-Naine', and 'Prata'.

The experimental plots with irrigation water depths consisted of three rows of eight plants each, with a spacing of $2.5 \times 1.6 \mathrm{~m}$. The useful area of each plot corresponded to the six central plants, i.e. two plants per cultivar.

Fertilization was conducted according to the recommendation of the (COMISSÃO DE
FERTILIDADE DE SOLOS DE GOIÁS, 1988) being subdivided into three stages: fertilization at planting, establishment, and production. A total of $356 \mathrm{~kg} \mathrm{~N} \mathrm{ha}^{-1}, 425.28 \mathrm{~kg} \mathrm{P}_{2} \mathrm{O}_{5} \mathrm{ha}^{-1}$, and 708.56 $\mathrm{K}_{2} \mathrm{O} \mathrm{kg} \mathrm{ha}{ }^{-1}$ was applied. According to Teixeira et al. (2001), the large $K$ accumulation in the biomass of plants and the exportation of this nutrient by fruits imply that even in soils with good $\mathrm{K}$ reserves, potassic fertilizations at high doses are necessary, without which crop yield could decline rapidly. Thus, potassium content was increased in the last fertilization due to plant nutritional requirements. Fertilizer was broadcast distributed about $0.50 \mathrm{~m}$ from plants. Nutrient monitoring was performed by means of two soil analyses, the first before planting and the second at the beginning of flowering, at which a foliar analysis was carried out by using samples of leaf III from plants at the beginning of flowering.

Banana plantation received all cultural practices recommended according to technical recommendations such as weed control, thinning, dried leaves removal, cutting off the flower bell (debelling), cutting the pseudostem down after harvest (MOREIRA, 1999).

Irrigations were carried out weekly for two months from the second week after planting until crop establishment with an average of $22.5 \mathrm{~mm}$ applied per irrigation event. Treatments were applied from July 25, 2001.

A drip irrigation system with two lines of drippers per crop row and emitters spaced every $0.3 \mathrm{~m}$ and with a flow rate of $1.02 \mathrm{~L} \mathrm{~h}^{-1}$ was used. Crop water requirement $\left(\mathrm{ET}_{\mathrm{pc}}\right)$ was estimated daily from a class A evaporation pan (CAP), corrected by crop (Kc) (DOORENBOS; PRUITT, 1977) and pan $(\mathrm{Kp})$ coefficients (DOORENBOS; KASSAM, 1994). Irrigations were carried out in order to supplement the precipitation regime, considering the accumulated $\mathrm{ET}_{\mathrm{pc}}$ of a given period when it totaled $50 \%$ of water storage capacity in the soil up to a depth of $0.40 \mathrm{~m}$. 
The critical level established in the experiment, i.e. the consumption of $50 \%$ of total water availability corresponded to a soil water stress of $100 \mathrm{kPa}$, which is within the range recommended by Klar (1991). For banana cultivation, the maximum water stress levels in the soil for periods of low and high evapotranspiration are from 30 to $150 \mathrm{kPa}$, respectively. Thus, the criterion of $50 \%$ of water storage capacity in the soil was adopted, which is within the recommended range for this crop.

Soil physical and physical water characterization was conducted considering the soil layers of $0-0.20$ $\mathrm{m}$ and $0.20-0.40 \mathrm{~m}$ in order to obtain the basic information for irrigation planning and management. Volumetric moisture at field capacity and permanent wilting point were obtained by using water retention curves in the soil for tensions of 10 and $1500 \mathrm{kPa}$, respectively. Based on the equations related to the retention curves, moisture at field capacity $\left(\theta_{\mathrm{fc}}\right)$ and permanent wilting point $\left(\theta_{\text {PWP }}\right)$ were 0.3437 and $0.2488 \mathrm{~m}^{3} \mathrm{~m}^{-3}$ at the layer of $0-0.20 \mathrm{~m}$, respectively, which corresponds to a water storage capacity in the soil of $18.98 \mathrm{~mm}$. At the layer of $0.20-0.40$ $\mathrm{m}, \theta_{\mathrm{fc}}$ was $0.3295 \mathrm{~m}^{3} \mathrm{~m}^{-3}$ and $\theta_{\text {PWP }}$ was $0.2176 \mathrm{~m}^{3}$ $\mathrm{m}^{-3}$, corresponding to a storage capacity of 22.38 $\mathrm{mm}$. Thus, the total water storage capacity in the soil at the depth of $0-0.40 \mathrm{~m}$ was $41.36 \mathrm{~mm}$. The time of each irrigation was determined by the ratio between crop potential evapotranspiration and water application intensity.

Harvest was carried out when fruits reached their maximum point of commercial maturity, i.e. fruits with maximum growth, slight corners, and completely greens. After harvesting, bunches were washed, hands were removed from them, and the mass of hands and stalk, length, diameter, and the number of commercial fruits were determined.

Genotype yield characterization was performed with the following assessments: BM - bunch mass $(\mathrm{kg})$; SM - stalk mass (kg); HM - hand mass (kg); $\mathrm{M} 2 \mathrm{H}$ - mass of the second hand; NH - number of hands; NFH - number of fruits per hand; FD2H fruit diameter of the second hand (mm); FL2H fruit length of the second hand (mm); TNF - total number of fruits; and NDF - number of damaged fruits. Productivity was obtained by multiplying the average bunch mass by the number of plants per hectare.

In the genotype "FHIA 18", a loss of a treatment (water depth $2-\mathrm{WD}_{2}$, corresponding to $65 \%$ of $\mathrm{ET}_{\mathrm{pc}}$ ) occurred due to the exchange of genotypes in the seedling acquisition. Data were submitted to analysis of variance by using the software SAS (STATISTICAL ANALYSIS SYSTEMS, 1997) and means compared by the Student's t-test at 5\% probability. Regression equations were adjusted for the assessed characteristics that showed the effect of irrigation depth application. From the estimated equations, graphs with response curves and the respective coefficients of determination were elaborated.

\section{Results and Discussion}

The results of analysis of variance of the productive behavior variables are shown in Table 1 . In the bunch characterization, during the first cycle harvest, a significant effect of irrigation water depth was observed only for the genotype "FHIA 18". $\mathrm{BM}, \mathrm{SM}$, and $\mathrm{M} 2 \mathrm{H}$ were significantly influenced $(\mathrm{P}<0.01)$ by irrigation water depths $\left(\mathrm{WD}_{\mathrm{i}}\right)$ only in the genotype 'FHIA 18'. This showed that the genotype 'FHIA 18' presented a greater sensitivity to irrigation use. The average productivity of the other assessed genotypes was above the Brazilian average, showing no significant influence of irrigation water depths (Table 2). 
Table 1. Analysis of variance and F-test of bunch mass (BC), mass of the second hand (M2H), number of hands (NH), number of fruits per hand (NFH), fruit diameter of the second hand (FD2H), fruit length of the second hand (FL2H), total number of fruits (TNF), and number of damaged fruits (NDF) of banana cultivars in the first production cycle submitted to four irrigation water depths with statistical breakdown for factors and their interactions. Goiânia, GO, Brazil.

\begin{tabular}{|c|c|c|c|c|c|c|c|c|c|}
\hline \multirow{2}{*}{$\mathrm{SV}^{1}$} & \multirow{2}{*}{$\mathrm{DF}^{2}$} & \multicolumn{7}{|c|}{$\mathrm{MS}^{3}$} & \multirow[b]{2}{*}{ NDF } \\
\hline & & $\mathrm{BM}$ & $\mathrm{M} 2 \mathrm{H}$ & $\mathrm{NH}$ & $\mathrm{NFH}$ & $\mathrm{FD} 2 \mathrm{H}$ & $\mathrm{FL} 2 \mathrm{H}$ & TNF & \\
\hline Block & 3 & - & - & - & - & - & - & - & - \\
\hline$W D i^{4}$ & 3 & $44.23^{\mathrm{ns}}$ & $1.09^{\text {ns }}$ & $0.82^{\text {ns }}$ & $2.14^{\mathrm{ns}}$ & $16.93^{* *}$ & $9.33^{*}$ & $381.54^{\mathrm{ns}}$ & $1.4473^{*}$ \\
\hline $\mathrm{Ra}^{5}$ & 9 & 12.83 & 0.71 & 0.94 & 4.76 & 2.42 & 1.42 & 328.44 & $0.1093^{\text {ns }}$ \\
\hline $\mathrm{G}^{6}$ & 2 & $675.89^{* *}$ & $13.16^{* *}$ & $10.77^{* *}$ & $123.07^{* *}$ & $38.74^{* *}$ & $101.51^{* *}$ & $8717.89^{* *}$ & $0.6789^{* *}$ \\
\hline WDixG & 5 & $38.45^{*}$ & $0.83^{\text {ns }}$ & $0.52^{\text {ns }}$ & $5.38^{\text {ns }}$ & $3.66^{\text {ns }}$ & $4.69^{* *}$ & $523.62^{\text {ns }}$ & $0.2595^{\mathrm{ns}}$ \\
\hline $\mathrm{R} \mathrm{b}^{7}$ & 20 & 12.79 & 0.33 & 0.59 & 3.71 & 1.95 & 1.06 & 245.48 & 0.0983 \\
\hline WDi/G & 8 & - & - & - & - & - & - & -- & \\
\hline $\mathrm{WDi} / \mathrm{F}^{8}$ & 2 & $134.59^{* *}$ & $3.01^{* *}$ & - & - & $1.63^{\text {ns }}$ & $18.70^{* *}$ & $1672.11^{* *}$ & $0.5029^{*}$ \\
\hline R.L L $^{9}$ & 1 & $41.59^{\text {ns }}$ & $0.55^{\text {ns }}$ & - & - & - & $0.56^{\mathrm{ns}}$ & $1.00^{\text {ns }}$ & $1.0035^{* *}$ \\
\hline D. R $^{10}$ & 1 & $227.60^{* *}$ & $5.48^{* *}$ & - & - & - & $38.88^{* *}$ & $3343.21^{* *}$ & $0.00231^{\text {ns }}$ \\
\hline WDi/Gn ${ }^{11}$ & 3 & $0.25^{\text {ns }}$ & $0.16^{\mathrm{ns}}$ & - & - & $4.40^{\text {ns }}$ & $0.91^{\mathrm{ns}}$ & $50.84^{\mathrm{ns}}$ & $1.4924^{* *}$ \\
\hline R.L & 1 & - & - & - & - & - & - & - & $3.6114^{* *}$ \\
\hline R. . $^{12}$ & 1 & - & - & - & - & - & - & - & $0.1204^{\mathrm{ns}}$ \\
\hline D.R & 1 & - & - & - & - & - & - & - & $0.7455^{* *}$ \\
\hline WDi/P13 & 3 & $9.67^{\text {ns }}$ & $0.25^{\mathrm{ns}}$ & - & - & $17.83^{* *}$ & $3.36^{*}$ & $33.18^{\text {ns }}$ & $0.0955^{\text {ns }}$ \\
\hline R.L & 1 & - & - & - & - & $31.49^{* *}$ & $5.02^{*}$ & - & - \\
\hline R.Q & 1 & - & - & - & - & $20.17^{* *}$ & $3.75^{\mathrm{ns}}$ & - & - \\
\hline D.R & 1 & - & - & - & - & $1.83^{\text {ns }}$ & $1.31^{\mathrm{ns}}$ & - & - \\
\hline$R(a+b)$ & 29 & 12.80 & 0.46 & - & - & 2.10 & 1.18 & 273.13 & 0.0966 \\
\hline
\end{tabular}

${ }^{1} \mathrm{SV}$ - Source of variation; ${ }^{2} \mathrm{DF}$ - Degrees of freedom; ${ }^{3} \mathrm{MS}$ - mean sum of squares; ${ }^{4} \mathrm{WDi}$ - Irrigation water depth; ${ }^{5}$ R. a - Residue a; ${ }^{6} \mathrm{G}$ - Genotype; ${ }^{7} \mathrm{R}$.b - Residue b; ${ }^{8} \mathrm{FHIA} 18 ;{ }^{9} \mathrm{R}$.L - Linear regression; ${ }^{10} \mathrm{D}$.R - Regression deviation; ${ }^{11}$ Grande Naine; ${ }^{12}$ R.Q - Quadratic regression; ${ }^{13}$ Prata.

The variables $\mathrm{NH}$ and $\mathrm{NFH}$ in the assessed genotypes 'FHIA 18', 'Grande-Naine', and 'Prata' had no influenced by irrigation depth application. This is probably due to the amount of water available in the soil during the establishment and much of the vegetative development periods since a good precipitation distribution occurred in the period from September 2001 to March 2002, as shown in Figure 1. This result is in accordance with Doorenbos and Kassam (1994), who state that the initial stage determines growth and fruiting potential. Water deficit in these stages may affect leaf development and influence the number of flowers, hands, and bunch production. This is reinforced by the results obtained by Braga Filho et al. (2011) in the Cerrado region of Goiânia in a planting carried out in January, in which irrigation water depths influenced productive characteristics of all studied genotypes.

Studying the effect of irrigation depth reduction from five months after planting on the productive behavior of the cultivar BRS Platina, Castricini et al. (2012) observed that the best yield in average fruit mass was obtained with no water restriction whereas the worst results were observed mainly when water 
restriction occurred at the stage between flowering and harvest. These authors also observed that fruits with the highest length $(21.7 \mathrm{~cm})$ and diameter $(45.1$ $\mathrm{cm})$ were obtained when full irrigation $\left(100 \% \mathrm{ET}_{\mathrm{pc}}\right)$ was applied at all crop stages. On the other hand, the lowest values were found with water restriction

at the stage between flowering and harvest.

Table 2. Average values of the production variables, estimated productivity $\left(\mathrm{P}_{\mathrm{e}}\right)$, number of hands $(\mathrm{NH})$, fruit diameter of the second hand (FD2H), fruit length of the second hand (FL2H), number of fruits per bunch (NFB), and number of damaged fruits (NDF) as a function of irrigation water depths (WDi). Goiânia, GO, Brazil.

\begin{tabular}{|c|c|c|c|c|c|}
\hline \multirow[b]{2}{*}{ Variable } & \multirow[b]{2}{*}{ WDi } & \multicolumn{3}{|c|}{ Genotype } & \multirow[b]{2}{*}{$\mathrm{CV}(\%)^{3}$} \\
\hline & & FHIA 18 & Grande-Naine & Prata & \\
\hline \multirow{4}{*}{$\begin{array}{c}P_{\mathrm{e}} \\
\left(\mathrm{t} \mathrm{ha}^{-1}\right)\end{array}$} & $30 \% \mathrm{ET}_{\mathrm{pc}}^{4}$ & $55.08 a^{1}$ & $76.80 \mathrm{a}$ & $40.17 b$ & \multirow{4}{*}{15.03} \\
\hline & $65 \% \mathrm{ET}_{\mathrm{pc}}$ & - & $76.77 \mathrm{a}$ & $48.15 \mathrm{~b}$ & \\
\hline & $90 \% \mathrm{ET}_{\mathrm{pc}}$ & $69.17 \mathrm{a}$ & $76.00 \mathrm{a}$ & $48.00 \mathrm{~b}$ & \\
\hline & $135 \% \mathrm{ET}_{\mathrm{pc}}$ & $36.77 \mathrm{~b}$ & $77.52 \mathrm{a}$ & $43.20 \mathrm{~b}$ & \\
\hline \multirow{4}{*}{$\mathrm{NH}$} & $30 \% \mathrm{ET}_{\mathrm{pc}}$ & $9.00 \mathrm{a}$ & $8.63 a$ & $6.88 \mathrm{~b}$ & \multirow{4}{*}{9.3} \\
\hline & $65 \% \mathrm{ET}_{\mathrm{pc}}$ & - & $9.00 \mathrm{a}$ & $7.50 \mathrm{~b}$ & \\
\hline & $90 \% \mathrm{ET}_{\mathrm{pc}}$ & $9.25 \mathrm{a}$ & $8.88 a$ & $7.75 b$ & \\
\hline & $135 \% \mathrm{ET}_{\mathrm{pc}}$ & $7.98 \mathrm{a}$ & $8.88 \mathrm{a}$ & $7.25 \mathrm{a}$ & \\
\hline \multirow{4}{*}{$\begin{array}{l}\text { FD2H } \\
(\mathrm{mm})\end{array}$} & $30 \% \mathrm{ET}_{\mathrm{pc}}$ & $39.17 \mathrm{a}$ & $39.91 \mathrm{a}$ & $34.33 \mathrm{~b}$ & \multirow{4}{*}{3.56} \\
\hline & $65 \% \mathrm{ET}_{\mathrm{pc}}$ & - & $40.88 a$ & $38.50 \mathrm{~b}$ & \\
\hline & $90 \% \mathrm{ET}_{\mathrm{pc}}$ & $39.53 a b$ & $40.66 \mathrm{a}$ & 38.74 b & \\
\hline & $135 \% \mathrm{ET}_{\mathrm{pc}}$ & $40.57 a b$ & $41.29 \mathrm{a}$ & $38.38 \mathrm{~b}$ & \\
\hline \multirow{4}{*}{$\begin{array}{l}\mathrm{FL} 2 \mathrm{H} \\
(\mathrm{cm}) \\
\end{array}$} & $30 \% \mathrm{ET}_{\mathrm{pc}}$ & $16.83 \mathrm{~b}$ & $23.13 \mathrm{a}$ & $17.63 \mathrm{~b}$ & \multirow{4}{*}{5.07} \\
\hline & $65 \% \mathrm{ET}_{\mathrm{pc}}$ & - & $23.69 \mathrm{a}$ & $19.63 \mathrm{~b}$ & \\
\hline & $90 \% \mathrm{ET}_{\mathrm{pc}}$ & $20.56 \mathrm{~b}$ & $23.38 \mathrm{a}$ & $19.31 \mathrm{c}$ & \\
\hline & $135 \% \mathrm{ET}_{\mathrm{pc}}$ & $16.51 \mathrm{c}$ & $22.56 \mathrm{a}$ & $19.38 \mathrm{~b}$ & \\
\hline \multirow{4}{*}{ NFB } & $30 \% \mathrm{ET}_{\mathrm{pc}}$ & $129.00 \mathrm{ab}$ & $148.00 \mathrm{a}$ & $99.00 \mathrm{~b}$ & \multirow{4}{*}{12.36} \\
\hline & $65 \% \mathrm{ET}_{\mathrm{pc}}$ & - & $146.13 \mathrm{a}$ & $100.75 \mathrm{~b}$ & \\
\hline & $90 \% \mathrm{ET}_{\mathrm{pc}}$ & 161.17 a & $140.00 \mathrm{a}$ & $104.34 \mathrm{~b}$ & \\
\hline & $135 \% \mathrm{ET}_{\mathrm{pc}}$ & $119.83 \mathrm{~b}$ & $146.75 \mathrm{a}$ & $97.75 \mathrm{c}$ & \\
\hline
\end{tabular}



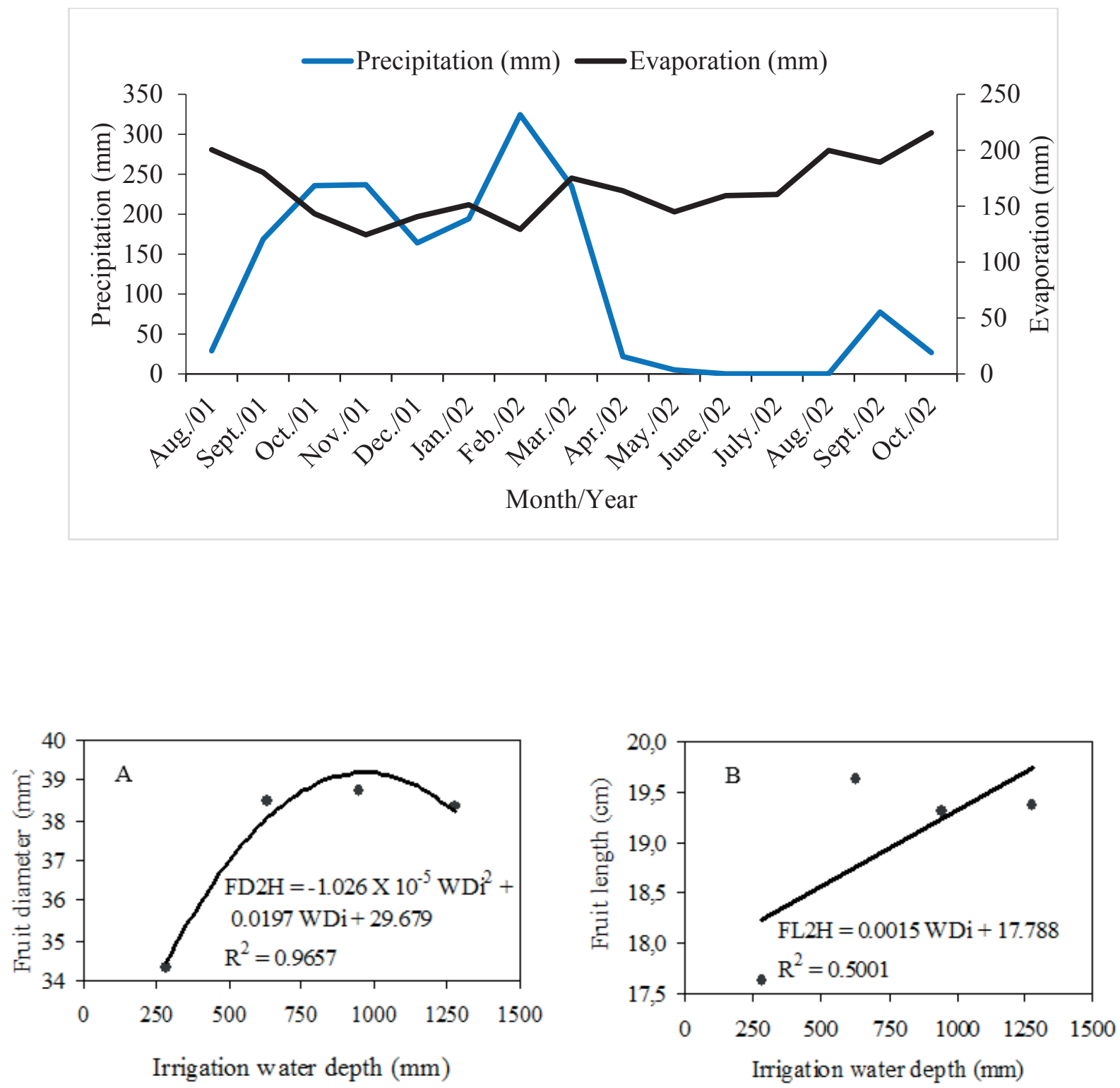

\begin{tabular}{|c|c|c|}
\hline \multirow{4}{*}{$\mathrm{NDF}^{2}$} & $30 \% \mathrm{ET}_{\mathrm{pc}}$ & $1.75 \mathrm{ab}$ \\
\hline & $65 \% \mathrm{ET}_{\mathrm{pc}}$ & - \\
\hline & $90 \% \mathrm{ET}_{\mathrm{pc}}$ & $0.50 \mathrm{a}$ \\
\hline & $135 \% \mathrm{ET}_{\mathrm{pc}}$ & 0.06 a \\
\hline \multicolumn{3}{|c|}{$\begin{array}{l}{ }^{1} \text { Means followed by the same letter in the lines, between } \\
\text { genotypes, do not differ from each other by the Student's test at } \\
5 \% \text { probability. }{ }^{2} \text { Values transformed into } \sqrt{x}_{\mathrm{x}}+0.5 \mathrm{~b} ;{ }^{3} \text { Coefficient } \\
\text { of variation }(\mathrm{CV}) .{ }^{4} \mathrm{ET}_{\mathrm{pc}} \text { (crop potential evapotranspiration). }\end{array}$} \\
\hline
\end{tabular}

Figure 1. Seasonal distribution of precipitation and evaporation 3 guring the experiment conduction period.

Goiânia, GQ.8Baziazil.

Figure 2. Fruit diameter (A) and fruit length (B) of the second han $2^{5}$ of the genotype $3{ }^{3}$ arata' as a function of irrigation Qraceadepths (WDil.13 a

Irrigation water depths presented a significant effect $(\mathrm{P}<0.01)$ on FD2H in the cultivar 'Prata'. Figure 2 shows the response curve for fruit diameter as a function of the applied irrigation water depth. The water depth that provided the largest diameter 
was $965 \mathrm{~mm}$, close to the water depth of $100 \% \mathrm{ET}_{\mathrm{pc}}$ (crop potential evapotranspiration) of $949.6 \mathrm{~mm}$. Martins et al. (2011) observed in banana 'Willians' cultivated in the Middle Paranapanema region, São Paulo, Brazil, positive responses for both irrigation and potassic fertilization on this variable.

Regarding the variable FL2H, an influence of irrigation water depths was observed in the genotypes 'FHIA 18' and 'Prata'. Fruit length increased linearly as water depth was increased in the cultivar 'Prata' (Figure 2). In relation to production destination, irrigation is also important for fruits destined to the market for in natura consumption since external and visible characteristics give the fruits a greater commercial value, mostly those larger in length and diameter. The increased irrigation water depth promoted an increase in length and diameter of fruits from the genotypes 'FHIA 18' and 'Prata'. Braga Filho et al. (2011) and Martins et al. (2011) also observed the positive effect of irrigation on fruit length.

Among the characteristics of each genotype, fruit size is dependent on the rhythm of leaf emission and plant size. Without water stress (or other stress), plants present a greater possibility of producing larger and better fruits. According to Soto Balestero (1992), finger growth by elongation of ovaries (length) starts four days before flowering and increases considerably up to 30 days after flowering. Diameter increases for a longer time (up to 90 days) depending on cultivation conditions, being strongly influenced by climatic conditions in the flowering period.

Although the consumer market prefers larger fruits, no economic analysis was conducted in this study. Thus, it becomes improper to say that a given irrigation water depth and the diameter produced by it are economically profitable, i.e. is it viable to apply an irrigation water depth that provides larger fruits? Goenaga et al. (1995) carried out an economic analysis of conduction and implantation of banana plantations in Puerto Rico and observed that the increased costs due to the use of irrigation were compensated by the increased production and fruit quality. Based on this economic analysis, these authors observed that an irrigation water depth of $100 \%$ evaporation of class A pan presented a higher production associated with a lower cost.

Only in the genotype 'FHIA 18', irrigation water depths influenced NFH. However, a functional relationship between treatments and cultivar was undetectable. Braga Filho et al. (2011) developed a study in the same region and observed that the genotype 'FHIA 18' presented a quadratic response

to irrigation water depths for most variables such as bunch mass and the total number of fruits.
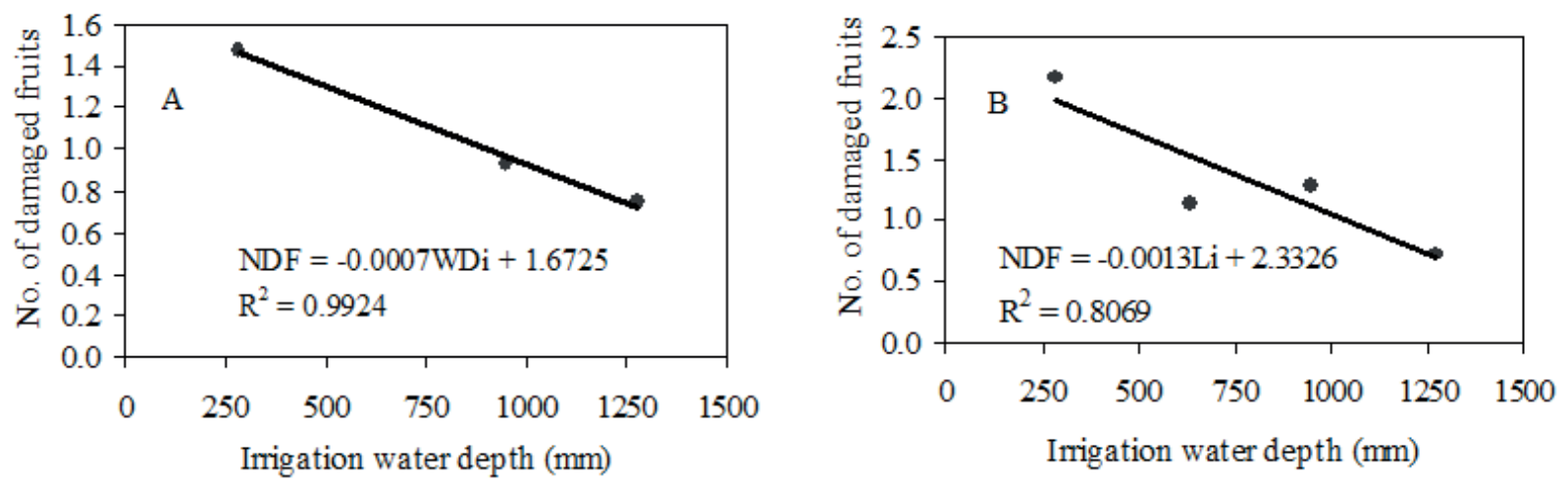
The number of damaged fruits in the genotypes 'FHIA 18 ' and 'Grande-Naine' decreased linearly with the applied water depth, presenting as damages smaller fruits of non-commercial size and weight (Figure 3). According to Robinson and Gálan Saúco (2010), a banana plant submitted to water stress produces small bunches and fruits, with a reduction in the yellow coloring of the peel, or even darkened and brittle. This demonstrates the importance of irrigation, especially when fruits are destined to a consumer market more demanding in quality.

Figure 3. Number of damaged fruits (NDF) in the genotypes 'FHIA 18' (A) and 'Grande-Naine' (B) as a function of irrigation water depths (WDi).

No influence of irrigation was observed on productivity for the genotypes 'Grande-Naine' and 'Prata'. The only influence was observed on the qualitative characteristics (diameter and length of fruit), mainly in the genotype 'Prata'. However, in studies conducted by Braga Filho et al. (2011) in the Cerrado region, the influence of irrigation was observed on production characteristics of the genotype 'Grande-Naine'.

"Grande-Naine" presented the earliest cycle with mush of the growth and development under soil water availability, without any influence from irrigation water depths. When comparing the total cycle of the assessed genotypes, 'Grande-Naine' was earlier and 'FHIA 18' was later. The genotypes 'Grande-Naine', 'Prata', and 'FHIA 18' presented an average total cycle of 361,408 , and 422 days, a vegetative cycle of 247,253 , and 281 days, and a productive cycle of 114, 155, and 140 days, respectively. Santos et al. (2006) consider that cycle is an essential variable for banana breeding since it expresses its precocity. In studies carried out in the Cerrado region by using the genotypes 'FHIA 18', 'Grande-Naine', Thap Maeo, and 'Prata', Braga Filho et al. (2008) found higher average values for total cycle and productivity. Although the genotype comparison was out of focus in this study, the averages for the assessed variables are shown in
Table 2.

Despite the lack of influence from irrigation depths, the genotypes 'Grande-Naine' and 'Prata' reached higher average yields if compared to the Brazilian average. The calculated average productivity for the genotypes 'Grande-Naine', 'Prata', and 'FHIA 18' was $76.8,44.9$, and $53.7 \mathrm{t}$ $\mathrm{ha}^{-1}$. The cultivar 'Prata' is vigorous, producing in low-fertility soils with water deficit, but presenting a low productivity even under irrigated conditions, reaching 20-25 t ha ${ }^{-1}$ (ALVES, 1999). However, under the conditions of this study, this cultivar reached a higher productivity.

The total evaporation in the class A pan and the total precipitation during the experimental period were 2,478.0 and 1,719.2 $\mathrm{mm}$, respectively. The lowest irrigation water depths were required during the months from October 2001 to March 2002 and the highest from April to October 2002, with an average evaporation of $5.80 \mathrm{~mm} \mathrm{day}^{-1}$. No control treatment was used in this study due to the planting season, i.e. due to the assumption that in the Cerrado region water is required throughout the crop cycle in order to obtain a good development, thus requiring irrigation.

The genotypes 'Grande-Naine' and 'Prata' had no influence on productive potential because most of the vegetative development occurred under soil water availability, that is, a good rainfall distribution over the experimental period. Thus, plants found good conditions to establish and develop well in the next rainy season. This behavior is due to the interaction between genotype and the environment since each genotype presents a distinct behavior due to the increased soil water levels. This occurs because of the physiological variation among genotypes since some of them have a greater ability to save water when compared to others. Braga Filho et al. (2011) and Coelho et al. (2013) also observed that different genotypes of banana and plane tree presented distinct behavior as a function of irrigation water depths. 
In addition to water depths, it might be appropriate to study different planting times since the water demand of banana crop is due, among other factors, to differences between planting season, as well as physiological characteristics inherent to cultivars and local edaphoclimatic conditions. The results obtained by Braga Filho et al. (2011) are in accordance with these statements since they observed that, due to regional characteristics, the use of irrigation becomes relevant to supply the water requirement of this crop at certain stages of growth and development when they occurred during a dry season. However, the productive activity should target the consumer market, which presents information that determines the investment level to be used. The use of new genotypes has been necessary since the appearance of phytosanitary problems, mainly the black Sigatoka. Thus, the genotype 'FHIA 18', which is resistant to this disease, despite being unsuited for the conservative consumer market, it becomes an alternative for cultivation at small farms and domestic orchards.

\section{Conclusions}

The genotypes 'FHIA 18', 'Grande-Naine', and 'Prata' presented different productive behavior due to the use of irrigation. Productivity and qualitative characteristics of fruit were positively influenced by the application of irrigation in the genotype 'FHIA 18'. The use of irrigation improved the biometric characteristics of fruits of these genotypes.

Banana genotypes 'FHIA 18', 'Grande-Naine', and 'Prata' presented a high average productivity (53.7, 76.8, and $44 \mathrm{t} \mathrm{ha}^{-1}$, respectively) under Cerrado conditions.

\section{Acknowledgements}

To Manoel Inácio da Silva (in memoriam) and Natal José Eufrásio for the support in the fieldwork. To the colleagues Paulo Henrique Silva, Ananda Vírginia de Aguiar for the support in conducting the experiment and statistical analysis. To the Coordination for the Improvement of Higher Education Personnel (CAPES) for granting the research scholarship to the second author. To the Federal Institute of Goiás (IF Goiano) for the financial support.

\section{References}

ALVES, E. J. A cultura da banana: aspectos técnicos, socioeconômicos e agroindustriais. 2. ed. Brasília: Embrapa - SPI, 1999. 585 p.

ASSAD, E. D.; EVANGELISTA, B. A. Análise frequencial da precipitação pluviométrica. In: ASSAD, E. D. Chuvas no cerrado: análise espacialização. Brasília: EMBRAPA/CPAC, 1994. p. 25-42.

BORGES, R. S.; SILVA, S. O.; OLIVEIRA, F. R.; ROBERTO, R. S. Avaliação de genótipo de bananeira no norte do Estado do Paraná. Revista Brasileira de Fruticultura, Jaboticabal, v. 33, n. 1, p. 291-296, 2011.

BRAGA FILHO, J. R.; NASCIMENTO, J. L.; NAVES, R. V.; SILVA, L. B.; PEREIRA, A. C. C. P.; GONÇALVES, H. M.; RODRIGUES, C. Crescimento de cultivares de bananeira irrigadas. Revista Brasileira de Fruticultura, Jaboticabal, v. 30, n. 4, p. 981-988, 2008.

BRAGA FILHO, J. R.; NASCIMENTO, J. L.; NAVES, R. V.; TORRES, M. C. L.; GERALDINE, R. M.; SOUZA, E. R. B.; BARROSO, F. V. Lâminas de irrigação e genótipos na produção e qualidade de frutos de bananeira. Pesquisa Agropecuária Tropical, Goiânia, v. 41, n. 2, p. 155-162, 2011.

CAMOLESI, M. R.; NEVES, C. S. V. J.; MARTINS, A. N.; SUGUINO, E. Desempenho de cultivares de bananeiras na região do Médio Paranapanema. Semina: Ciências Agrárias, Londrina, v. 33, n. 1, p. 2931-2938, 2012.

CASTRICINI, A.; COELHO, E. F.; RODRIGUES, M. G. V.; COUTINHO, R. C. Caracterização pós-colheita de frutos de bananeira BRS Plantina de primeiro ciclo, sob regulação do déficit de irrigação. Revista Brasileira de Fruticultura, Jaboticabal, v. 34, n. 4, p. 1013-1021, 2012.

COELHO, E. F.; OLIVEIRA, R. C.; PAMPONET, A. J. M. Necessidades hídricas de bananeira tipo Terra em condições de tabuleiros costeiros. Pesquisa Agropecuária Brasileira, Brasília, v. 48, n. 9, p. 1260-1268, 2013.

COMISSÃO DE FERTILIDADE DE SOLOS DE GOIÁS. Recomendações de corretivos e fertilizantes para Goiás. 5 $5^{\text {a }}$ Aproximação. Goiânia: UFG/Engopa, 
1988. $101 \mathrm{p}$.

DOORENBOS, J.; KASSAM, A. H. Efeito da água no rendimento das culturas. Campina Grande: UFPB, (FAO. Irrigação e Drenagem, 33). 1994. 306 p.

DOORENBOS, J.; PRUITT, W. O. Crop water requeriment. Rome: FAO, 1977. 144 p.

FOOD AND AGRICULTURE ORGANIZATION - FAO. FAOSTAT. Agriculture produticion. Crops primary. Taxa de crescimento de importação, exportação e produção de frutas. Rome: FAO, 2014. Available at: <http://www.fao. org/faostat/es/\#data/QC>. Accessed at: 29 jan. 2014.

GOEDERT, W. Região dos Cerrados: potencial agrícola e política para seu desenvolvimento. Pesquisa Agropecuária Brasileira, Brasilia, v. 24, n. 1, p. 1-17, 1989.

GOENAGA, R.; IRIZARY, H.; COLEMAN, B.; ORTIZ, E. Drip irrigation recommendations for plantain and banana grown on the semiarid southern coast of Puerto Rico. Agronomy Journal, Puerto Rico, v. 79, n. 1-2, p. 13-27, 1995.

INSTITUTO BRASILEIRO DE GEOGRAFIA E ESTATÍSTICA - IBGE. Produção agrícola municipal. Brasília: IBGE, 2015. Disponível em: <http://www.sidra. ibge.gov.br/bda/prevsaf $>$. Acesso em: 14 mar. 2015.

KLAR, A. E. Irrigação: frequência e quantidade de aplicação. São Paulo: Nobel, 1991. 156 p.

LICHTEMBERG, L. A.; LICHTEMBERG, P. S. F. Avanços da bananicultura brasileira. Revista Brasileira de Fruticultura, Jaboticabal, E. 029-036, p. 29-36, 2011. Número Especial.

MARTINS, A. N.; TEIXEIRA, L. A. J.; SUGUINO, E.; HASHIMOTO, J. M.; NARITA, N. Irrigação e adubação potássica via fertirrigação em bananeira Willians produção e qualidade de frutos. Revista Brasileira de Fruticultura, Jaboticabal, p. 743-751, 2011. Volume Especial.

MOREIRA, R. S. Banana: teoria e prática de cultivo. $2^{\text {th }}$ ed. Campinas: Fundação Cargill, 1999. 1667 p. CDROM.

NIMER, E.; BRANDÃO, A. M. P. M. Balanço hídrico e clima da região dos Cerrados. Rio de Janeiro: IBGE, Departamento de Recursos Naturais e Estudos Ambientais, 1989. 166 p.

NOMURA, E. S.; DAMATTO JÚNIOR, E. R.; FUZITANI, E. J.; AMORIM, E. P.; SILVA, S. O. E. Avaliação agrônomica de genótipos de bananeiras em condições subtropicais, Vale do Ribeira, São Paulo. Revista Brasileira de Fruticultura, Jaboticabal, v. 35, n. 1, p. 112-122, 2013.

RAMOS, D. P.; LEONEL, S.; MISCHAN, M. M.; DAMATTO JÚNIOR, R. Avaliação de genótipos de bananeira em Botucatu - SP. Revista Brasileira de Fruticultura, Jaboticabal, v. 31, n. 4, p. 1092-1102, 2009.

ROBINSON, J. C.; GALÁN SAÚCO, V. Bananas and plantains. $2^{\text {th }}$ ed. Oxford: CAB International, 2010. 311 p. (Crop Production Science in Horticulturae Series, 19).

SANTOS, S. C.; CARNEIRO, L. C.; ILVEIRA NETO, A. M.; PANIAGO JÚNIOR, E.; PEIXOTO, C. N. Caracterização morfológica e avaliação de cultivares de bananeira resistentes a Sigatoka-negra (Mycosphaerella fijiensis Morelet) no sudoeste goiano. Revista Brasileira de Fruticultura, Jaboticabal, v. 28, n. 3, p. 449-453, 2006.

SOTO BALESTERO, M. Bananos: cultivo y comercialización. San José: Litografia e Imprenta LIL, 1992. 674 p.

STATISTICAL ANALYSIS SYSTEM INSTITUTE - SAS Institute. SAS/Stat software: changes and enhancements through release 6.12. Cary: SAS Institute Inc., 1997.

TEIXEIRA, A. H. C. Uso de estações meteorológicas automáticas no manejo de irrigação de fruteiras. ITEM, Brasília, n. 51, p. 22-26, 2001. 
